UDC: $658.8-339.1$

http://doi.org/10.21272/mmi.2019.3-03

JEL Classification: M31; L66

Yusuf Arslan,

Ph.D., Business School, Sakarya University, Turkey

\title{
EXPLORING THE EFFECTS OF CONSUMERS' NUTRITIONAL KNOWLEDGE AND INFORMATION INTEREST ON THE ACCEPTANCE OF ARTIFICIAL SWEETENER USAGE IN SOFT DRINKS
}

Abstract. Together with the increasing health awareness levels of consumers', artificial food additives have been highly criticized by the public. However, these kinds of sweeteners are still being used widely all over the world. One of the sectors that prefer mostly these kinds of sweeteners is the soft drink industry. High fructose corn syrup, which has been associated with serious health problems recently, is one of these additives which is highly preferred in the soft drink industry. Upon examining the situation, it is understood that there is a conflict between the implementations of the soft drink industry and consumer attitudes towards them. However, it is seen that the consumers' perspective is not clarified enough empirically in terms of this issue. This means that the players of the soft drink industry have a lack of insight in terms of consumer thoughts and attitudes regarding artificial sweetener usage in soft drinks. Owing to this research gap in the literature and the importance of the subject in terms of consumer well-being, this study aims to explore the antecedents for the acceptance of high fructose corn syrup usage in soft drinks. To reach this aim, four research questions represented to understand how frequent consumers prefer soft drinks containing high fructose corn syrup, to reveal consumers' attitudes and acceptance towards high fructose corn syrup and to understand how nutritional knowledge and nutritional information interest affect consumers' acceptance specifically on high fructose corn syrup usage in soft drinks. To answer these questions, a structured survey was developed and conducted on 888 soft drink consumers who are aware of high fructose corn syrup in soft drinks as an additive. Then, a number of analyses were conducted with the data obtained. According to the results, it is seen that although participants have a quite negative attitude towards HFCS usage in soft drinks (2.13 out of seven points Likert), more than half of them (53\%) declared that they frequently buy soft drinks that contain HFCS. As to the hypothesis of the research, it is concluded that nutritional knowledge and nutritional information interest were both negatively affects consumer acceptance of high fructose corn syrup usage in soft drinks. The results suggest that the antecedents studied in this paper are both significant. Thus the two hypotheses of the study were supported. Obtaining these findings, this study contributes to the literature by creating insight in terms of consumer acceptance of artificial sweetener usage in soft drinks which is crucial especially in terms of consumer health.

Keywords: artificial sweeteners, consumer acceptance, consumer health, food additives, soft drinks.

Introduction. Soft drink consumption has become an important public health \& policy issue recently and it has been hypothesized as one of the major factors for different kind of diseases [The soft drinks included in the present study are bottled and processed drinks like coke, juices, energy drink, floured sodas, ice tea, etc. which contain artificial sweeteners]. The literature review indicates that soft drink intake increases the risk of obesity, diabetes, cardiovascular disease, development of gout and metabolic syndrome and etc. (See: Bray et al., 2004; Forshee, 2007; Bray, 2013; Basu et al., 2013). The World Health Organization (WHO) has lately laid stress on the need to evaluate different behavioural change approaches to increase the reduction of free sugars intake; especially, the intake of sugarsweetened drinks (who.int, 2015). Besides, governmental organizations across the globe are conducting awareness-increasing activities to point the availability of soft drinks at schools (Hawkes 2010). Soft drinks have been completely banned or strictly limited to consume at schools in Britain, France, the United States and Turkey, etc. (Vartanian et al., 2007; meb.gov.tr, 2016). One of the main reasons for the soft drinks to be harmful to human health is due to the primary artificial sweetener that is called high fructose corn syrup (HFCS) (Nseir et al., 2010). However, it is quite popular among soft drink companies to use HFCS because it is cheaper to produce than regular sugar (Beghin, 2006). Although governments

Cite as: Arslan, Y. (2019). Exploring the Effects of Consumers' Nutritional Knowledge and Information Interest on the Acceptance of Artificial Sweetener Usage in Soft Drinks. Marketing and Management of Innovations, 3, 33-44. http://doi.org/10.21272/mmi.2019.3-03 

Artificial Sweetener Usage in Soft Drinks

have been challenging with the usage of HFCS in the food \& drink industry, it has never been easy to win this increasingly competitive battle owing to the cost advantages it provides.

In 2017, the HFCS production was 640 thousand tonnes for all European Union (EU) countries in total. Until recently, there was an average of $2 \%$ HFCS quota for sugar production in the EU countries (gidabilgi.com 2018). But with the removal of the quota (europa.eu, 2017), after long years, HFCS production is likely to increase for the EU countries. The historical background of HFCS usage in Turkey has been quite different from the developed EU countries. Turkey had a 7th place in the world in 2017 in terms of sugar consumption with 2,425 million tons (isosugar.org, 2018). HFCS producers have been much luckier because the quota was higher for Turkey than it is for EU members. However, Turkey recently has done something to reduce HFCS production. HFCS quota, which was $10 \%$ in Turkey for many years, has been reduced to $5 \%$ by the government. Thus, while the quota for 2017 was 267 thousand tons, this amount was determined as 133,500 tons for 2018 (turkseker.gov.tr, 2018). Besides, with the rising health awareness in Turkish society regarding food preferences (gidahatti.com, 2018), the attitude towards HFCS consumption is turning into negative. However, although the government has charged $10 \%$ extra taxes for soft drinks recently (gib.gov.tr 2018); it is not easy to claim that these preventions were enough to reduce consumption. HFCS production is still quite high and it is on average about one-fifth of all European production for Turkey. It is clear that something else needs to be done to reduce the consumption of these artificial additives, parallel to the suggestions of WHO.

Given the strong socio-cultural role of food (Douglas and Isherwood, 1979), the relative weighting of the different attitudes affecting food choice is expected to vary between nations (Pettigrew et al., 2015). Thus, to solve this problem that the Turkish market faces, the issue needs to be investigated within its own context. Following this principle, this study was undertaken in the Turkish context. Following this perspective, the main aim of the present study is to understand the effects of consumers' nutritional knowledge (NK) and nutritional information interest (NII) on the acceptance of soft drinks with HFCS. Simultaneously, it has been aimed to understand the Turkish consumers' attitudes on soft drinks sweetened with HFCS. It is also targeted to reveal the Turkish consumers' acceptance, NK and NII levels together with soft drink consuming frequency. Hence, the following research questions are addressed in the present study:

1. How often do consumers prefer soft drinks that contain HFCS?

2. What are the consumer's general attitudes towards HFCS usage in soft drinks? And to what extent are consumers accepting HFCS usage in soft drinks?

3. What are the nutritional knowledge and nutritional information interest levels of consumers? And does it vary regarding gender or between participants with/without children?

4. To what extent consumers' nutritional knowledge and nutritional information interest influence their acceptance of HFCS usage in soft drinks?

Literature Review. In their everyday life, consumers have to make many food choices associated with food additives and form attitudes towards food additives as well as foods. And once these attitudes are formed, it is not easy to change them (Martins et al., 1997). Therefore, to help consumers to form either good or bad attitudes towards certain food additives, it is crucial to understand the determinants of consumer acceptance. There are not quite many empirical studies about this topic and the studies, which focused on additive acceptance of consumers, are handled mostly on general food additives (Bearth et al., 2014). Although the literature review reveals that consumers have negative feelings about artificial food additives (Tarnavolgy, 2003), there are not many studies mentioning specific additives such as HFCS. It seems like an important research gap due to the fact that consumers might form different attitudes towards different kinds of food additives such as preservatives, food colorants or sweeteners. Moreover, the acceptance of consumers may vary according to specific food additive (Eiser et al., 2002). To this end, the current study investigated the research model represented in Fig. 1 for the specific 
Y. Arslan. Exploring the Effects of Consumers' Nutritional Knowledge and Information Interest on the Acceptance of Artificial Sweetener Usage in Soft Drinks

sweetener HFCS which has been widely used in soft drinks. Via this choice, this study will have the potential to provide information regarding the acceptance specifically for HFCS rather than food additives in general. This is a significant issue especially in terms of consumer well-being considering the scientific knowledge that we have regarding health issues caused by HFCS consumption.

The importance of the naturalness of foods for a person might also be effective in the decision to accept food additives. In their study, Beath et al. (2014) concluded that consumer preferences for natural products negatively influence the acceptance of artificial additive usage in food products. Considering the consumers who have high NK levels, it can be claimed that they are more conscious in terms of knowing which food products are healthier for them (Barreiro et al. 2010). With this point of view, we may put forward that aforementioned relationship should also be valid between NK and the acceptance of HFSC usage in soft drinks. Moreover, according to the study of Stern and Meixner (2009), consumers' pre-knowledge about food additives influences their attitudes towards them. Thus, if a consumer has the right knowledge about HFCS as an additive being used in the soft drinks, it is quite expectable that s/he is accepted to generate negative attitudes towards it. Although there are studies in the literature claiming that NK does not necessarily lead to the actual purchase of healthy products (Brown et al. 2000), it is mostly considered as positively associated with healthful food choices (Barreiro et al., 2010; Spronk et al., 2014). In both cases, it is reasonable to claim that NK levels of consumers would be associated with the acceptance of HFCS contained soft drinks regardless of actual purchase behavior. However, this relationship is expected to be negative considering that HFCS is perceived as an unhealthy food additive. In this regard, the hypothesis is proposed as follows;

H1: Consumers' nutritional knowledge negatively influences their acceptance of HFCS usage in soft drinks.

$\mathrm{NII}$ is also an important antecedent regarding the acceptance of HFCS usage in soft drinks. There are studies in the literature indicating that NII may not be enough to change the consumers' attitudes towards a certain product. In one of these studies, Williams et al. (2004) figured out that consumers' distrust of food additives might be stemmed from incomplete understanding, misinformation or lack of knowledge. Established attitudes towards certain kinds of food were difficult to overcome by the provision of nutrition information. In a preceding study, Martins et al. (1997) also ascertained that nutrition information rarely changed the attitudes of the consumers who had regarded certain foods as disgusting beforehand. But what if consumers' attitudes are still not well established? Then NII might become an important issue in terms of creating those attitudes. Besides, according to the results of some other studies, the levels of consumers' NII vary between product categories. In one of these studies conducted by the Nordic Council (2004), it was stated that consumers mostly care about NII for processed products with low degrees of transparency such as fast food instead of fresh products like meat or vegetables. Considering soft drinks are highly processed products, it can also be expected from the consumers to check its nutritional information.

Consequently, the interest in nutritional issues can be expected to influence all consumer behaviour processes regarding food products (Grunert and Wills, 2007) and this also ought to comprise the acceptance of certain food products or additives. Since HFCS contained soft drinks provide only empty calories to the human body, which means extra energy with no nutrients (Bere et al., 2007), there is a high possibility for a person who is interested in nutritional information not to accept this product after reading the information. Thus, the hypothesis is proposed as follows;

H2: Consumers' nutritional information interest negatively influences the acceptance of HFCS usage in soft drinks.

The hypotheses of the study are illustrated in the conceptual model presented in Fig. 1. In order to avoid potential confounding effects on the dependent variable, age and gender are controlled. The reason for choosing the age and gender specifically is due to the fact that they were both used as control 
Y. Arslan. Exploring the Effects of Consumers' Nutritional Knowledge and Information Interest on the Acceptance of Artificial Sweetener Usage in Soft Drinks

variables in the previous studies (Siders et al., 2001; Murray et al., 2017) and were found to influence people's attitudes and decision making (Mitchell and Walsh, 2004). Thus, age and gender are thought to account for variation in the acceptance of HFCS usage in soft drinks.

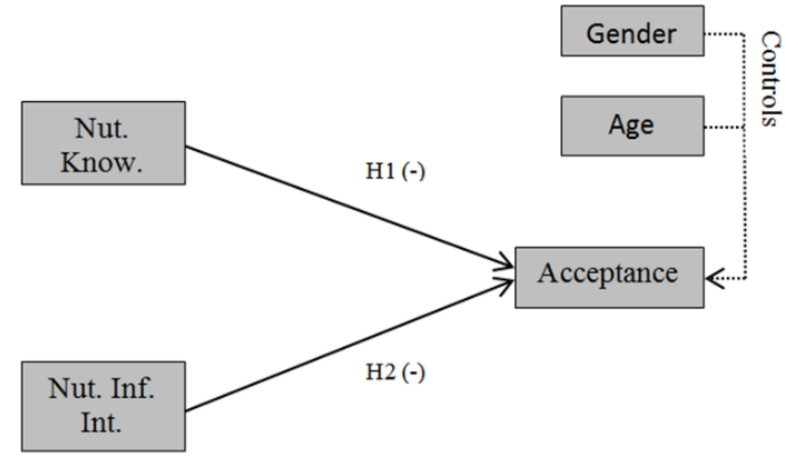

Figure 1. Proposed Research model

*Nut. Know.: Nutritional Knowledge; Nut. Inf. Int.: Nutritional Information Interest; Acceptance: Acceptance of HFCS usage in soft drinks

Methodology and research methods. The population of this study consists of Turkish consumers who are above the age of 18 and aware of HFCS usage in soft drinks. The respondents were chosen via a quota sampling method from six different age groups that represent the age distribution of Turkish people according to the report of the Turkish Statistical Institute (TUIK, 2018). A questionnaire was administered to collect the data and "drop and collect" data collection technique was employed in this study following Coviello et al. (2002), which makes it possible to yield response rates similar to a personadministered approach at a cost equivalent to questionnaire mail outs. At the end of the data collection, after removing incomplete surveys and the irrelevant responses within the scope (e.g. the surveys that were filled out although the participants didn't hear about HFCS at all), a total of 888 usable survey forms were obtained. As the survey instrument was originally designed in English, it was necessary to translate the items into Turkish before administration. The process involved two rounds of translation, first from English into Turkish and then back translation from Turkish into English, to ensure that the original meanings of the scale items were captured (O'Cass et al., 2013).

Existing measures drawn from the literature were used in this study. The studies of Bearth et al. (2014) for Acceptance (AC); Balasubramanian and Cole (2002) for Nutritional Interest (NI); Desai and Ratneshwar (2003) for Nutritional Knowledge (NK) and for Attitudes (ATD) Pettigrew at al. (2015). Multi-item levels to measure $\mathrm{AC}, \mathrm{NI}$ and NK relied on a five-point Likert scale. Only ATD's were measured on a seven-point semantic differential scale. Also, another question was added to the questionnaire to be able to see how often the participants prefer soft drinks that contain HFCS. The answers were; don't know about HFCS, never, occasionally, sometimes and often. 98 people who declared they don't know about HFCS were not added to the sample of the study. Further, the survey was pre-tested before the application by using expert judges including marketing and food engineering academics who had previous experience in the subject area to check for readability, flow and conceptual clarity of the surveys. After the consultation with the experts, some minor modifications were made to the structure of the survey. Also, in order to control for a potential common method bias, different scale formats have been used to avoid artefactual covariation produced by the use of the same scale format (Podsakoff et al., 2003). Additionally, the questionnaire used in the study was designed to include the endogenous variables prior to exogenous ones (Murray et al., 2005). The items used in the study can be seen in Table 1. 
Y. Arslan. Exploring the Effects of Consumers' Nutritional Knowledge and Information Interest on the Acceptance of Artificial Sweetener Usage in Soft Drinks

Table 1. The Scales Used in the Study

\begin{tabular}{|c|c|}
\hline Measure & ource \\
\hline \multicolumn{2}{|l|}{ Acceptance - 5 Points Likert } \\
\hline $\begin{array}{l}\text { - AC1- I pass certain drinks up because they contain HFCS. } \\
\text { - AC2- I have more important things to do than worry about HFCS.(R) } \\
\text { - AC3- It does not bother me if my drink contains HFCS. I } \\
\text { - AC5- I think it is unimportant to check on the packaging whether a soft drink } \\
\text { contains HFCS. I } \\
\text { - AC6- HFCS cannot be harmful; otherwise, they would not be contained in so } \\
\text { many drinks. I } \\
\text { - AC7- People give too much thought to HFCS. I }\end{array}$ & $\begin{array}{l}\text { Adapted from Bearth et al. } \\
(2014)\end{array}$ \\
\hline \multicolumn{2}{|l|}{ Nutritional Information Interest - 5 Points Likert } \\
\hline $\begin{array}{l}\text { - NII1- Today, I was interested in looking at the nutritional information on the soft } \\
\text { drink package. } \\
\text { - NII2- I look at the nutritional information on soft drink bottles regularly. } \\
\text { - NII3-I think that the nutritional information panels on soft drink bottles provide } \\
\text { very useful information.X } \\
\text { - NII4- I regularly use the nutritional information provided on soft drink bottles. }\end{array}$ & $\begin{array}{l}\text { Adapted from } \\
\text { Balasubramanian and Cole, } \\
(2002)\end{array}$ \\
\hline \multicolumn{2}{|l|}{ Nutritional Knowledge - 5 Points Likert } \\
\hline $\begin{array}{l}\text { - NK1- Whenever I buy a soft drink, I check its nutritional information.X } \\
\text { - NK2- In general, I prefer to drink low-calorie soft drinks. } \\
\text { - NK3- I usually get upset with myself when I drink beverages with harmful } \\
\text { contaminants. } \\
\text { - NK4- I pay very close attention to the kind of soft drink I prefer. }\end{array}$ & $\begin{array}{l}\text { Adapted from Desai et al., } \\
(2003)\end{array}$ \\
\hline \multicolumn{2}{|l|}{ Attitude- 7 Points Semantic Differential } \\
\hline $\begin{array}{ll}\text { - } & \text { bad/good, } \\
\text { - } & \text { healthy/unhealthy, } \\
\text { - } & \text { bad for children/good f }\end{array}$ & $\begin{array}{l}\text { Adapted from, Pettigrew et } \\
(2015)\end{array}$ \\
\hline
\end{tabular}

$X=$ Items that were eliminated based on the results of exploratory factor analysis; $R=$ Reverse coded item

Sources: adapted by the author from the existing studies in the literature

In order to achieve the purpose of this study and to test the proposed hypotheses, SPSS 20 and AMOS 21 statistics programs were used. SPSS 20 was used to find out the demographic characteristics of the sample, to obtain Cronbach's a values, to calculate means and to conduct t-test. And in the second step, confirmatory factor analysis was conducted to prove the validity of each instrument, while structural equation modelling was used to test hypotheses via AMOS 21.

Results. The age range of the respondents was between 18 and 69. The most crowded group was the respondents between the ages of 20-29. Since quota sampling was used as the sampling method, the age distribution was indeed close to the actual distribution of Turkish citizens. Gender and marital status are evenly distributed ( $49.7 \%$ female, $50.3 \%$ male \& $52.4 \%$ married, $47.6 \%$ single respectively). Education level can also be regarded as evenly distributed besides the respondent with post-graduate education (4.2\%). Lastly, the monthly income level of respondents is mostly between 1000 to 4000 Turkish Liras as illustrated in Table 2.

The mean values of the respondents' answers are given in Table 3. It is understood that the participants of the study frequently buy these soft drinks (53\% sometimes or more frequently-RQ1). But it does not necessarily mean that they found it healthy or preferable by looking at their attitudes. It is understood that Turkish customers have quite negative attitudes about HFCS usage in soft drinks considering their score of 2.13 (seven points Likert). As to acceptance levels, it is seen that consumers' 
Y. Arslan. Exploring the Effects of Consumers' Nutritional Knowledge and Information Interest on the Acceptance of Artificial Sweetener Usage in Soft Drinks

answers are nearer to the negative side with 2.75. Although the acceptance levels are inclined to be negative, it is still relatively high $(\mathrm{RQ} 2)$.

Table 2. Sample profile

\begin{tabular}{|c|c|c|c|}
\hline \multirow{2}{*}{ Demographics } & \multirow{2}{*}{ Classification } & \multicolumn{2}{|c|}{$\mathrm{n}=888$} \\
\hline & & $f$ & $\%$ \\
\hline \multirow{2}{*}{ Gender } & Male & 441 & 49.7 \\
\hline & Female & 447 & 50.3 \\
\hline \multirow{2}{*}{ Marital Status } & Married & 465 & 52.4 \\
\hline & Single & 423 & 47.6 \\
\hline \multirow{2}{*}{ Children } & Yes & 411 & 46.3 \\
\hline & No & 477 & 53.7 \\
\hline \multirow{6}{*}{ Age } & 19 and below & 65 & 7.3 \\
\hline & $20-29$ & 324 & 36.5 \\
\hline & $30-39$ & 183 & 20.6 \\
\hline & $40-49$ & 153 & 17.2 \\
\hline & $50-59$ & 115 & 13.0 \\
\hline & 60 and over & 47 & 5.3 \\
\hline \multirow{5}{*}{ Level of Education } & Primary \& Secondary & 171 & 19.3 \\
\hline & High school & 333 & 37.5 \\
\hline & Associate & 140 & 15.5 \\
\hline & University & 205 & 23.1 \\
\hline & Post Graduate & 37 & 4.2 \\
\hline \multirow{5}{*}{ Monthly Income (TL) } & 1000 and below & 204 & 23 \\
\hline & $1001-2500$ & 325 & 36.6 \\
\hline & $2501-4000$ & 256 & 28.8 \\
\hline & $4001-5500$ & 72 & 6.8 \\
\hline & $5501+$ & 31 & 3.5 \\
\hline
\end{tabular}

Source: developed by the author based on the data obtained from the participants of the study

Table 3. Frequencies of the answers

\begin{tabular}{|l|l|l|l|l|l|}
\hline \multicolumn{1}{|c|}{ Variables } & \multicolumn{1}{|c|}{$\begin{array}{c}\text { Mean } \\
(\mathbf{n = 8 8 8})\end{array}$} & \multicolumn{1}{|c|}{ Scale } & Preference Frequency* & f & \% \\
\hline Nut. Int. & 3.19 & (5 points Likert) & Never Prefers & 62 & $7 \%$ \\
\hline Nut. Know. & 3.15 & (5 points Likert) & Occasionally & 354 & $39.9 \%$ \\
\hline Acceptance & 2.75 & (5 points Likert) & Sometimes & 276 & $31.1 \%$ \\
\hline Attitudes & 2.13 & (7Points Semantic Differential) & Often & 195 & $22.0 \%$ \\
\hline
\end{tabular}

${ }^{*}$ Preference frequency for HFCS used soft drinks. 98 people declared that they never heard about HFCS and excluded from the population of the study.

Source: developed by the author based on the data obtained from the participants of the study

According to the results, it is also seen that NK and NII levels of the customers' are quite similar $(\mathrm{NK}=3.15 ; \mathrm{NI}=3.19)$ and only slightly higher than three. Since " 3 " is the neutral point, it can be said that respondents NK and NII levels are only slightly positive. But it is certainly not easy to say that they have high levels of NK and NII (RQ 3).

Independent sample t-tests were conducted to be able to explore the differences between gender and the situation of having children in terms of NK and NII (RQ4). As to gender, distribution of the data was sufficiently normal for conducting the t-test (Skewness $=-.01<|2|$ and Kurtosis $=-1.9<|9|$; Schimder et al. (2010)). Additionally, the assumption of homogeneity of variances was tested and satisfied via 
Y. Arslan. Exploring the Effects of Consumers' Nutritional Knowledge and Information Interest on the Acceptance of Artificial Sweetener Usage in Soft Drinks

Levene's $F$ test, $F(886)=.03, p=.853$. According to the results of the independent samples t-test to reveal the differences of NK levels between gender, it is seen that the t-test was associated with a statistically significant effect, $t(886)=-5.2, p<.001$ and the females were associated with a significantly larger mean volume than males (Female= 3.33; Male= 2.95). Another independent t-test was conducted to reveal the difference between genders in terms of NII levels. The assumption of homogeneity of variances was tested and satisfied via Levene's $F$ test, $F(886)=.81, p=.368$. According to the results, $\mathrm{NII}$ levels are also significantly different between gender (Female= 3.30 ; Male= $3.07 ; \mathrm{t}(886)=-2.9$, $\mathrm{p}=.003$ ).

As to comparing the participants with or without children, the distribution of the data was also sufficiently normal for conducting the t-test (Skewness $=-15$ and Kurtosis=-1.9). The assumption of homogeneity of variances was significant according to the results of Levene's $F$ test, $F(886)=.6 .3$, $p=.012$. The results of the independent samples t-test aiming to reveal the differences NK levels between participants with or without children indicate that the independent samples t-test was associated with a statistically significant effect, $t(886)=4.50, p<.001$. The participants with children were associated with a significantly larger mean volume than participants without children (with children= 3.32; without= 2.99). Lastly, one more independent t-test was conducted to reveal the difference between the situation of having children in terms of NII levels. The assumption of homogeneity of variances was tested and satisfied via Levene's $F$ test, $F(886)=2.01, p=.156$. According to the results, also the NII levels are significantly higher for the participant who have children (with children= 3.41 ; without $=2.98 ; t(886)=5.49, p<.001)$.

The measurement model was estimated prior to testing the structural relationships proposed in the conceptual framework of the study. The psychometric properties of the scales were investigated by running a confirmatory factor analysis. The latent constructs were correlated, whereas the measurement items and their error items were constrained to be uncorrelated. After dropping certain items with low factor loadings, the validity of constructs was assessed by estimating the confirmatory measurement model. According to the result, the model displays acceptable goodness of fit index (Schermelleh-Engel and Moosbrugger, 2003) for the data as indicated by $X 2 / d f=3.532 ; p<.001 ; R M S E A=.049 ; G F I=.966$; AGFI=.947; CFI=.974; TLI=.966; NFI= .964.

Table 4 illustrates factor loadings, Cronbach's alpha and t values for the multi-item measures in the study.

Table 4. Reliability and validity

\begin{tabular}{|c|c|c|c|c|c|}
\hline Construct & Indicators & Standardized loadings & $\mathrm{t}$ values & $p$ & $\alpha$ \\
\hline \multirow[t]{3}{*}{ Nutr. Know. } & NK2 & .634 & 16,995 & *** & 0.77 \\
\hline & NK3 & .514 & 17,526 & *** & \\
\hline & NK4 & .687 & 17,535 & $* * *$ & \\
\hline \multirow[t]{3}{*}{ Nutr. Inf. Int. } & $\mathrm{NII1}$ & .852 & 29,612 & $\star * *$ & 0.88 \\
\hline & $\mathrm{NII2}$ & .853 & 30,212 & $\star * *$ & \\
\hline & $\mathrm{NII4}$ & .830 & 28,683 & *** & \\
\hline \multirow[t]{7}{*}{ Acceptance } & AC1 & .656 & 15,522 & $\star \star *$ & 0.87 \\
\hline & AC2 & .569 & 15,045 & $* * *$ & \\
\hline & $\mathrm{AC3}$ & .792 & 16,789 & $\star * *$ & \\
\hline & AC4 & .783 & 16,635 & $\star \star \star *$ & \\
\hline & AC5 & .685 & 15,425 & $\star * *$ & \\
\hline & AC6 & .751 & 16,312 & $\star * *$ & \\
\hline & AC7 & .639 & 14,664 & *** & \\
\hline
\end{tabular}

Source: developed by the author 
Y. Arslan. Exploring the Effects of Consumers' Nutritional Knowledge and Information Interest on the Acceptance of Artificial Sweetener Usage in Soft Drinks

Nut. Know. = Nutritional Knowledge of participants; Nut. Inf. Int. = Nutritional Information Interest of participants; Acceptance= Participants acceptance of HFCS usage in soft drinks; ${ }^{* * *}=p<.001$

In the next step, convergent and discriminant validity were assessed for the structures used in the research model. According to the suggestions of Anderson and Gerbing (1988), convergent validity can be assessed from the measurement model by determining whether or not each indicator's estimated pattern coefficient on its posited underlying construct factor is significant. Table 4 reveals that each item's factor loading is more than 0.50 , ranging between .51 and .85 . Also the t- values of the standardized loadings for these items measuring the same construct are statistically significant at the a $=0.001$ level. Thus it can be said that the indicator variables of this study have convergent validity. Fornell and Larcker (1981) criterion were used in this study to test the discriminant validity. AVE values for each construct exceeded the squared inter-construct correlations between them and any other construct included in the model as stated in Table 5. Thus, discriminant validity was achieved.

Table 5. Discriminant validity

\begin{tabular}{|l|c|c|c|c|c|}
\hline \multicolumn{1}{|c|}{ Variables } & Acceptance & Nutr. Knowledge & Nutr. Inf. Int. & CR & AVE \\
\hline Acceptance & $\mathbf{1}$ & 0.52 & 0.40 & 0.87 & 0.55 \\
\hline Nut. Knowledge & 0.52 & $\mathbf{1}$ & 0.45 & 0.74 & 0.54 \\
\hline Nut. Inf. Interest & 0.40 & 0.45 & $\mathbf{1}$ & 0.88 & 0.72 \\
\hline
\end{tabular}

Source: developed by the author

To avoid potential problems with multi-collinearity, the independent variables were mean-centered (Cohen et al., 2003). Path analysis was used to test the main effects of hypotheses $\mathrm{H} 1$ and $\mathrm{H} 2$. The model explained the $59 \%$ of the variance which is quite high. Without control variables, the model still explains $58 \%$ of the variance and the $\Delta X^{2}$ is 33.36 . The $R^{2}$ values of NK and NII were well above .26 as suggested by Cohen (1988), indicating a substantial model. According to the result, although the $X^{2}$ test of model fit was significant, the model fits well $(p<.001 ; x 2 / d f=3.266$; RMSEA $=.051 ; G F I=.969$; AGFI=.952; CFI=.977; TLI=.969; NFI= .968). After model fit for the structure was approved, hypotheses were tested with regard to two paths between NK, NII and acceptance $(\mathrm{H} 1 \& \mathrm{H} 2)$.

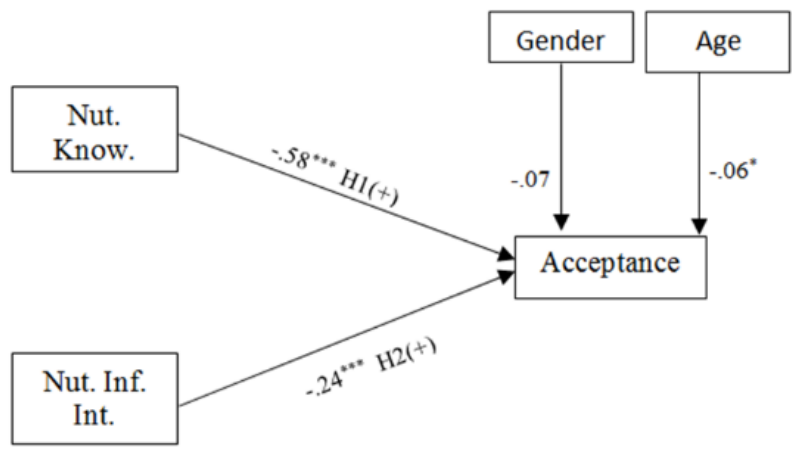

${ }^{*} p<.05 ;{ }^{* * *} p<.001$

Fig.2. Path analysis of factors influencing consumers' acceptance of HFCS usage in soft drinks

According to the results, nutritional knowledge significantly and negatively influences consumer acceptance $(B=.-58, p<.001)$. Also, nutritional information interest has a significant and negative effect on the acceptance of HFCS usage in soft drinks, explaining $58 \%$ of the variance. Thus $\mathrm{H} 1$ and $\mathrm{H} 2$ are 

Artificial Sweetener Usage in Soft Drinks

supported. Regarding control variables, while age has a significant effect on acceptance $(\beta=.06$, $p<.05)$, there is no significant relationship between gender and attitude $(B=.07, p>.05)$.

Conclusions. This study explored the effects of Turkish consumers' NK and NII on their acceptance of HFCS usage in soft drinks. In this section, some implications for HFCS acceptance in terms of NII and NK and suggestions for future research are presented. Empirical results obtained via SEM revealed that $\mathrm{NK}$ and NII are both significant antecedents regarding the acceptance of HFCS usage in soft drinks. This is an important result especially in terms of consumer well-being. To prevent consumers from consuming certain ingredients, the most important thing is to reveal what determines their acceptance. This study bridges the gap in the literature by dealing with this important issue. Considering the worldwide battle against HFCS and other harmful additives, it is quite important to understand the issue thoroughly.

Subsequently, attitudes are explored and NII and NK levels are compared between gender and participants with or without children specifically for Turkish consumers. It is seen that the attitudes of Turkish consumers are quite negative towards HFCS (2.13 out of 7 ). However, it is known from the literature that, compared to $27 \mathrm{EU}$ countries, Turkey is among the countries which have the lowest rates in terms of penetration of nutritional information given in the packages of soft drinks (Bonsmann et al., 2010). It is quite possible that this situation might arise either from the self-reported nature of the scales used in this study, or the other 26 EU countries would have got even lower rates from the same scale in terms of attitudes. Moreover, according to the results of another large-scale study $(n=3500)$, the average NII level of EU consumers are 3.49 (Hieke, et al., 2018). Accordingly, NII and NK levels of Turkish consumers can be regarded as low (3.19 and 3.15 out of 5 , respectively) compared to other EU countries. Thus, it can be said that Turkish consumers' NII and NK levels need to be increased to be able to reduce the acceptance level of HFCS usage in soft drinks. It is also important in terms of consumer well-being by considering the harms of HFCS to human health, which is scientifically proven.

One way to do it might be to change the nutritional information style at the soft drink bottles/packages. Nutritional information about a certain product mostly takes place at either the back or front of the product's package. According to the study of Machin et al. (2018), front of package nutrition labeling schemes effectively improved the average healthfulness of food choice by respondents. According to another study (Hawley et al., 2013), the nutrition information at the front of the packages can be more attention-grabbing and may empower consumers to identify unhealthy food products and to make more informed food choices. Considering that nutritional information mostly takes place at the back of the product packages in the Turkish market, it can be an effective way to change its position from back to front to benefit from the opportunities aforementioned.

It is also concluded that females and participants with children are significantly higher in terms of NII and NK scores. This finding corroborates with other studies on nutritional interest (Grunet et al., 2010; Hieke et al., 2018) and knowledge (Grunet and Wills, 2007). These results demonstrate that, despite varying between countries, consumers' reaction in terms of nutrition seems parallel to each other demographically. Thus, marketing professionals should keep in mind that demographic factors can be an excellent market dividing instrument.

NK and NII were assessed as antecedents of acceptance for HFCS usage in soft drinks within the scope of this study. However, NK appears to be more effective on the acceptance than NII with its bigger effect (.58>.24). Even so, it doesn't make NII less important. It is known from the literature that the more nutritional information a consumer has, the more NK s/he possibly will have (Hieke et al., 2018). Thus, by enhancing NII, it is also possible to increase the level of NK. This is the main reason why the practitioners should first target to increase the NII levels of Turkish consumers. The situation is not also easy for companies in Turkey selling natural soft drinks without harmful ingredients. Considering low NII levels of consumers, practitioners must put more emphasis on this issue by letting consumers know that their product does not include those kinds of artificial additives so that consumers would not need to find 

Artificial Sweetener Usage in Soft Drinks

out that valuable knowledge with their own effort. Because it is also an important issue in terms of consumer well being and there is a war going on between players of the sector and the government (considering new HFCS quotas for Turkish market), the government also needs to take more action by means of organizing campaigns via mass media regarding informing consumers about nutritional issues so that their NK levels can reach higher levels.

This study faces limitations mainly due to the self-reported nature of the collected data instead of actual data. In particular, three limitations are worth noting and suggest potentially fruitful avenues for future research. Firstly, the nature of the data offers certain caveats because of a lack of insights into actual HFCS contained soft drink consumption. An experimental design with the packages of real products would potentially generate better results. Secondly, only the effects of NII and NK were examined in this study. Adding other antecedents would potentially create new insights in terms of acceptance of HFCS. And lastly, this study was conducted specifically on the acceptance of HFCS usage in soft drinks. However, HFCS was used in many product categories. It would add to the literature to replicate this study on other products. Considering it is known from the literature that consumers' acceptance may differ for different ingredients, it would also contribute to the literature to replicate this study on other ingredients like other harmful sweeteners, etc.

\section{References}

Anderson, J.C. and Gerbing, D.W., 1988. Structural equation modelling in practice: A review and recommended two-step approach. Psychological Bulletin, 103(3), p.411.

Balasubramanian, S.K. and Cole, C., 2002. Consumers' search and use of nutrition information: The challenge and promise of the nutrition labeling and education act. Journal of Marketing, 66(3), pp.112-127.

Barreiro-Hurle, J., Gracia, A., and De-Magistris, T. (2010). Does nutrition information on food products lead to healthier food choices?. Food Policy, 35(3), pp.221-229.

Basu, S., McKee, M., Galea, G. and Stuckler, D., 2013. Relationship of soft drink consumption to global overweight, obesity, and diabetes: a cross-national analysis of 75 countries. American Journal of Public Health, 103(11), pp.2071-2077.

Bearth, A., Cousin, M.E. and Siegrist, M., 2014. The consumer's perception of artificial food additives: Influences on acceptance, risk and benefit perceptions. Food Quality and Preference, 38, pp.14-23.

Beghin, J.C., 2016. Biofuel and Feedstock Markets and the EU-US TTIP. Agricultural Policy Review, 2016(1), p. 2

Bere, E., Glomnes, E.S., te Velde, S.J. and Klepp, K.I., 2008. Determinants of adolescents' soft drink consumption. Public Health Nutrition, 11(1), pp.49-56.

Bonsmann, S.S., Celemin, L.F., Larranaga, A., Egger, S., Wills, J.M., Hodgkins, C. and Raats, M.M., 2010. Penetration of nutrition information on food labels across the EU-27 plus Turkey. European Journal of Clinical Nutrition, 64(12), p.1379.

Bray, G.A., 2013. Energy and fructose from beverages sweetened with sugar or high-fructose corn syrup pose a health risk for some people. Advances in Nutrition, 4(2), pp. 220-225

Bray, G.A., Nielsen, S.J. and Popkin, B.M., 2004. Consumption of high-fructose corn syrup in beverages may play a role in the epidemic of obesity. The American Journal of Clinical Nutrition, 79(4), pp.537-543.

Brown, K., Mcllveen, H. and Strugnell, C., 2000. Nutritional awareness and food preferences of young consumers. Nutrition \& Food Science, 30(5), pp.230-235.

Cohen, J., 1988. Statistical power analysis for the behavioral sciences. LEA

Cohen, P., West, S.G. and Aiken, L.S., 2014. Applied multiple regression/correlation analysis for the behavioral sciences. Psychology Press.

Coviello, N.E., Brodie, R.J., Danaher, P.J. and Johnston, W.J., 2002. How firms relate to their markets: an empirical examination of contemporary marketing practices. Journal of Marketing, 66(3), pp.33-46.

Desai, K.K. and Ratneshwar, S., 2003. Consumer perceptions of product variants positioned on atypical attributes. Journal of the Academy of Marketing Science, 31(1), pp.22-35.

Douglas, M. and Isherwood, B., 2002. The world of goods. Routledge.

Eiser, J.R., Miles, S. and Frewer, L.J., 2002. Trust, Perceived Risk, and Attitudes Toward Food Technologies 1. Journal of Applied Social Psychology, 32(11), pp.2423-2433.

Europa.eu., 2017. [cited 2019 Jan 09]. Available from: http://europa.eu/rapid/press-release_MEMO-17-3488_en.htm 
Y. Arslan. Exploring the Effects of Consumers' Nutritional Knowledge and Information Interest on the Acceptance of Artificial Sweetener Usage in Soft Drinks

Fornell, C. and Larcker, D.F., 1981. Structural equation models with unobservable variables and measurement error: Algebra and statistics. Journal of Marketing Research, pp.382-388.

Forshee, R.A., Storey, M.L., Allison, D.B., Glinsmann, W.H., Hein, G.L., Lineback, D.R., Miller, S.A., Nicklas, T.A., Weaver, G.A. and White, J.S., 2007. A critical examination of the evidence relating high fructose corn syrup and weight gain. Critical Reviews in Food Science And Nutrition, 47(6), pp.561-582.

Gib.gov.tr., 2018. [cited $2019 \mathrm{Jan}$ 07]. Available from: http://www.gib.gov.tr/fileadmin/mevzuatek/otv_oranlari_tum/03_ 07_2018_III_sayili_liste.pdf

Gidahatti.com., 2018. [cited 2019 Jan 07]. Available from: https://www.gidahatti.com/turkler-gida-secimlerini-neye-goreyapiyor-79870/

Grunert, K.G. and Wills, J.M., 2007. A review of European research on consumer response to nutrition information on food labels. Journal of Public Health, 15(5), pp.385-399.

Grunert, K.G., Wills, J.M. and Fernández-Celemin, L., 2010. Nutrition knowledge, and use and understanding of nutrition information on food labels among consumers in the UK. Appetite, 55(2), pp.177-189.

Hawkes, C., 2010. The worldwide battle against soft drinks in schools. American Journal of Preventive Medicine, 38(4), pp.457-461.

Hawley, K.L., Roberto, C.A., Bragg, M.A., Liu, P.J., Schwartz, M.B. and Brownell, K.D., 2013. The science on front-ofpackage food labels. Public Health Nutrition, 16(3), pp.430-439.

Isosugar.org., 2018. Quarterly Market Outlook, [cited 2019 Jan 05]. Available from: https://www.isosugar.org/publication/101/ iso-quarterly-market-outlook---february-2018

Machin, L., Aschemann-Witzel, J., Curutchet, M.R., Gimenez, A. and Ares, G., 2018. Does front-of-pack nutrition information improve consumer ability to make healthful choices? Performance of warnings and the traffic light system in a simulated shopping experiment. Appetite, 121, pp.55-62.

Martins, Y., Pelchat, M.L. and Pliner, P., 1997. "Try it; it's good and it's good for you": Effects of taste and nutrition information on willingness to try novel foods. Appetite, 28(2), pp.89-102.

Mitchell, V.W. and Walsh, G., 2004. Gender differences in German consumer decision-making styles. Journal of Consumer Behaviour: An International Research Review, 3(4), pp.331-346.

Murray, J.Y., Kotabe, M. and Zhou, J.N., 2005. Strategic alliance-based sourcing and market performance: evidence from foreign firms operating in China. Journal of International Business Studies, 36(2), pp.187-208.

Murray, J., Elms, J. and Teller, C., 2017. Examining the role of store design on consumers' cross-sectional perceptions of retail brand loyalty. Journal of Retailing and Consumer Services, 38, pp.147-156.

Nseir, W., Nassar, F. and Assy, N., 2010. Soft drinks consumption and nonalcoholic fatty liver disease. World Journal of Gastroenterology: WJG, 16(21), p.2579.

O'Cass, A., Jin Lee, W. and Siahtiri, V., 2013. Can Islam and status consumption live together in the house of fashion clothing?. Journal of Fashion Marketing and Management: An International Journal, 17(4), pp.440-459.

Pettigrew, S., Jongenelis, M., Chapman, K. and Miller, C., 2015. Factors influencing the frequency of children's consumption of soft drinks. Appetite, 91, pp.393-398.

Podsakoff, P.M., MacKenzie, S.B., Lee, J.Y. and Podsakoff, N.P., 2003. Common method biases in behavioral research: A critical review of the literature and recommended remedies. Journal of Applied Psychology, 88(5), p.879.

Schermelleh-Engel, K., Moosbrugger, H. and Müller, H., 2003. Evaluating the fit of structural equation models: Tests of significance and descriptive goodness-of-fit measures. Methods of Psychological Research Online, 8(2), pp.23-74.

Schmider, E., Ziegler, M., Danay, E., Beyer, L. and Bühner, M., 2010. Is it really robust?. Methodology.

Siders, M.A., George, G. and Dharwadkar, R., 2001. The relationship of internal and external commitment foci to objective job performance measures. Academy of Management Journal, 44(3), pp.570-579.

Spronk, I., Kullen, C., Burdon, C. and O'Connor, H., 2014. Relationship between nutrition knowledge and dietary intake. British Journal of Nutrition, 111(10), pp.1713-1726.

Stern, T., Haas, R. and Meixner, O., 2009. Consumer acceptance of wood-based food additives. British Food Journal, 111(2), pp.179-195.

Tarnavolgyi, G., 2003. Analysis of consumers attitudes towards food additives using focus group survey. Agriculturae Conspectus Scientificus, 68(3), pp.193-196.

Teksoz, F. 2018. [cited 2019 Jan 06]. Available from: http://gidabilgi.com/Makale/Detay/nisasta-bazli-seker-sektoru-dc243b

TUIK, 2018. Demographics in Turkey, [cited 2019 Feb 15]. Available from: http://www.tuik.gov.tr/UstMenu.do?metod=temelist, Turkish Ministry of Education, 2016. [cited 2019 Feb 16]. Available from: http://mevzuat.meb.gov.tr/dosyalar/1770.pdf,

Turkseker.gov.tr., 2018. Sector report, [cited 2019 Jan 09]. Available from: https://www.turkseker.gov.tr/sector-report-2018.pdf Vartanian, L.R., Schwartz, M.B. and Brownell, K.D., 2007. Effects of soft drink consumption on nutrition and health: a systematic review and meta-analysis. American Journal of Public Health, 97(4), pp.667-675.

Williams, P.G., Stirling, E. and Keynes, N., 2004. Food fears: a national survey on the attitudes of Australian adults about the safety and quality of food. Asia Pacific Journal of Clinical Nutrition, 3(1), pp. 32-39. 
Y. Arslan. Exploring the Effects of Consumers' Nutritional Knowledge and Information Interest on the Acceptance of Artificial Sweetener Usage in Soft Drinks

World health organisation, 2015. Sugar intake for adults and children, [cited 2019 Jan 09]. Available from:http://apps.who.int/iris/bitstream/handle/10665/149782/9789241549028_eng.pdf;jsessionid=B77D9E85AB4165852A6EC2E7 FA438D1D?sequence=1

Юсуф Арслан, Ph.D., Університет Сакар'я (Туреччина).

Вплив обізнаності та зацікавленості споживачів у принципах здорового харчування на рівень споживання безалкогольних напоїв із високим вмістом фруктози

Маркетингові дослідження ринку безалкогольних напоїв свідчать про падіння попиту на ию категорію товару внаслідок активної інфоормаційної пропаганди здорового образу життя населення. Однак, незважаючи на вищезазначений фракт виробники безалкогольних напоїв продовжують в якості иукорозамінників використовувати кукурудзяний сироп із високим вмістом фрруктози, який може призвести до серйозних проблем зі здоров'ям. Основною метою проведеного дослідження є вивчення ставлення споживачів до наявності кукурудзяного сиропу з високим вмістом фрруктози у товарах ринку безалкогольних напоїв. Поставлена мета дослідження зумовила необхідність вирішення наступних завдань: вивчення попиту споживачів на безалкогольні напої, які містять у своєму складі кукурудзяний сироп із високим вмістом фрруктози; дослідження впливу обізнаності та зацікавленості споживачів у принципах здорового харчування на рівень споживання безалкогольних напоїв із високим вмістом фруктози. Інформаційну базу дослідження склали результати опитування 888 споживачів безалкогольних напоїв з високим вмістом фрруктози. Результати проведеного статистичного аналізу даних свідчать, що незважаючи на негативне відношення учасників опитування до наявності кукурудзяного сиропу із високим вмістом фрруктози у безалкогольних напоях (2.13 бали за шкалою Лайкерта), більша частина респондентів (53\%) вказала на часте споживання безалкогольних напоїв, в складі яких наявний кукурудзяний сироп із високим вмістом фрруктози. Дослідження емпірично підтверджує та теоретично доводить висунуті в роботі гіпотези, що знання про харчові речовини та інтерес до здорового образу життя негативно впливають на сприйняття споживачами безалкогольних напоїв з високим вмістом кукурудзяного сиропу. Результати проведеного дослідження створюючи уявлення про сприйняття споживачами використання штучних підсолоджувачів в безалкогольних напоях, що має вирішальне значення для здоров'я споживачів.

Ключові слова: цукорозамінники, сприйняття споживачами товару, здоров'я споживача, харчові добавки, безалкогольні напої.

Manuscript received: 17.06.2019.

(C) The author(s) 2019. This article is published with open access at Sumy State University. 